\title{
SENDING LETTERS IN THE ANCIENT WORLD: PAUL AND THE PHILIPPIANS
}

\author{
Stephen Robert Llewelyn
}

\begin{abstract}
Summary
How did Paul maintain contact with believers in Philippi whilst he was imprisoned? Does the number of journeys implied in Philippians argue against the letter's composition in Rome? The conveyance of letters and news in antiquity is discussed with particular reference to the imperial post and the suggestion that Paul may have used it. The nature of the contact between Paul and the Philippians is investigated. The conclusion is reached that the Macedonian church most probably learned of Paul's despatch from Caesarea to Rome whilst he was en route. Epaphroditus may have already been in Rome when Paul arrived. The number of journeys implied in Philippians does not preclude a Roman provenance.
\end{abstract}

\section{Introduction}

C.J. Hemer' ${ }^{1}$ offers the suggestion that the 'sequences of journeys implied by Philippians are more easily explained within the facilities offered by the presence of Christian couriers in the imperial service to and from Rome (cf. Phil. $4: 22)$ '. In a footnote he continues: 'The journeys implied between Rome and Philippi were probably not all private and sequential, but part of a continuous passage of Christian intelligence by frequent travellers along the whole route. ${ }^{2}$ The

\footnotetext{
${ }^{1}$ C.J. Hemer, The Book of Acts in the Setting of Hellenistic History (Tübingen: Mohr, 1989) 273-75, 393. Hemer's suggestion offers an occasion to reconsider the nature of the contact between Paul and the Philippians and the related question of the epistle's place of composition. Though the suggestion might be viewed by many as dubious, it nevertheless allows one to focus the discussion and provides a useful position against which the nature and mechanics of the contact can be understood.

2Ibid, 274 n. 59.
} 
proposition is that there were Christian slaves and/or freedmen of Caesar's household who, as tabellarii (couriers), used the facilities of the imperial post and who could be imposed upon whilst performing their official duties to carry private letters and news between Paul imprisoned in Rome and the community of believers situated at Philippi. ${ }^{3}$ The proposition rests on the number of journeys implied in the text of the letter.

The first journey must be inferred from the Philippians' response in sending Epaphroditus with their gift to Paul. How and from whom they learned of Paul's situation is unknown. The second journey is that of Epaphroditus who brought the Philippians' gift to Paul in prison (Phil. 4:10, 14 and 18; cf. also 1:7). He may also have carried news about the dispute between Euodia and Syntyche (Phil. 4:2). The third and fourth journeys relate to the news of Epaphroditus' illness. The Philippians had heard that he was sick and news of this had in turn distressed Epaphroditus (Phil. 2:26). It is unclear whether these messages were written or oral. It is also unclear who the bearers of the news were. The fifth journey is that of Epaphroditus who returning to Philippi carried Paul's letter to the believers there (Phil. 2:25). Sixth and seventh journeys are anticipated. Paul hopes to send Timothy to the Philippians 'so that I may be

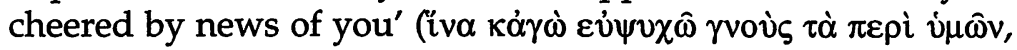
Phil. 2:19). As well the apostle trusts that he will be able to visit them in person at some time in the near future (Phil. 2:24).

The following discussion is based on three assumptions. They are: (a) that the letter to the Philippians was written by Paul; (b) that the letter is not a composite of two or more letters; and (c) that the letter was written from Rome. All assumptions have been questioned. With regard to (a) and (b) the onus of proof rests with those who would dispute the assumptions for the simple reason that the letter presents itself as a unity written by Paul. It is my view that contrary arguments are not sufficient to dislodge the ostensible form of

${ }^{3}$ Hemer does not seem to entertain the possibility that the believing members of Caesar's household were administrative officials situated in Rome and able to arrange couriers to carry messages for them. Soldiers of the praetorian guard ( $c f$. Phil. 1:13), or other soldiers for that matter, also come to mind as possible couriers. 
the letter. Assumption (c) is more difficult in that the letter gives no overt indication of where it was written. Ephesus, Caesarea and Rome have all been postulated.

Arguments in favour of a Roman provenance are the stronger. ${ }^{4}$ One of the principal arguments against it is that the number of journeys implied in the letter (four prior to its being written) and the duration of and interval between each reduces the likelihood of a Roman origin. ${ }^{5}$ The suggestion that Paul used imperial couriers is a counter to this argument and used by Hemer to support his contention that Philippians was written late in Paul's imprisonment at Rome. As I hope to show, all arguments on this point are misconceived, for the reason that only the third and fourth journeys should be factored into any calculation here. Time is no longer a constraining consideration. However, before turning to a discussion of the evidence of Philippians regarding these journeys, we must look more carefully at Hemer's suggestion that imperial couriers might have been used to carry personal letters or news. External and internal evidence will be discussed in that order.

\section{The Post in the Ancient World}

There was no public system for the conveyance of private letters or news in antiquity. Instead, the postal systems, be they of the Persian, Hellenistic or Roman empire, were created for official use. No doubt, officials from time to time used the system to send personal correspondence.

Badian $^{6}$ suggests that Ptolemaic officials used the postal service for private items and could be prevailed upon by others to accept their items as well. Evidence for the suggestion is not cited by Badian. The status of the items delivered by the two Phoenix brothers in P. Hibeh I 110 is problematic; it is unclear

4For a recent discussion of the question of the letter's provenance, see P.T. O'Brien, The Epistle to the Philippians (Grand Rapids: Eerdmans, 1991) 1926.

5It would take approximately forty days to travel between Rome and Philippi.

6E. Badian, 'Postal Service', Oxford Classical Dictionary, 869. 
what function the brothers played in the postal system and whether the rolls delivered by them were personal or official. 7

There is also little evidence for a private use of the Roman postal system. The reasons for this are quite apparent. Cities and dependent communities are unlikely to have complained as the abuse did not compound the burden of maintaining the cursus publicus, for in each case the courier had to make the journey anyway. Nor is it likely that a private letter would mention its means of conveyance, if this involved the abuse of an official position. One possible example may, however, be cited. It is a fourth-century Christian letter which was

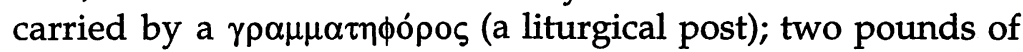
tow were to be carried by the same courier on the return trip. 8 The practice appears to have changed in the later centuries. In the later Byzantine period (sixth to seventh century $A D$ )

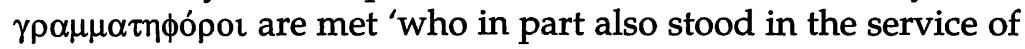
private individuals'. ${ }^{9}$

It may not have always been possible to differentiate easily between official and personal correspondence. Be that as it may, the establishment of postal systems became a necessity, as Holmberg 10 observes, with the growth of empires. In Holmberg's analysis the development of an organised system of communication and transport within each empire was a function of the size of its dominion, the political power which it wielded and the tendency to centralise administration. Only thus could it justify the costs of such a system.

The postal systems of Persia and the Hellenistic kingdoms, as far as we can tell, operated by relays of couriers on horseback. ${ }^{11}$ Speed was of the essence. An important innov-

7See further S.R. Llewelyn, 'Did the Ptolemaic postal system work to a timetable?', ZPE 99 (1993) 50-51.

${ }^{8} S B$ XIV 11881. For further discussion of this text, see S.R. Llewelyn, New Documents Illustrating Early Christianity, vol. 7 (Sydney: AHDRC 1994) 4849.

${ }^{9}$ U. Wilckens, Grundzüge und Chrestomathie der Papyruskunde, I, 1 (repr. Hildesheim: Olms, 1963) 374.

${ }^{10}$ E.J. Holmberg, Zur Geschichte des Cursus Publicus (Uppsala dissertation, 1933) 17.

${ }^{11}$ On the Persian system, see Herodotus, Hist. 8.98, and Xenophon, Cyr. 8.6.17-18. On the Ptolemaic system, see P. Hibeh I 110 and the discussions 
ation to the system was made by Augustus, as Suetonius (Augustus 49.3) noted:

To enable what was going on in each of the provinces to be reported and known more speedily and promptly, he at first stationed young men (iuvenes) at short intervals along the military roads, and afterwards post-chaises (vehicula). The latter has seemed the more convenient arrangement, since the same men who bring the dispatches (litteras) from any place can, if occasion demands, be questioned as well.

Augustus made a significant change to the organisation of the system. He replaced the relay of couriers by a relay of vehicles, thus taking the defining step in the creation of what was to be known as the cursus publicus. The latter became an extensive system for official transportation consisting of change-stations (mutationes) at intervals of 8-10 milia passum $(1 \mathrm{mp} \approx 1.5 \mathrm{~km})$ with mansiones (change-stations with overnight quarters) at a day's journey apart (approximately $25 \mathrm{mp}$ ). The change-stations were supplied with between 8 and 40 animalia publica $(e . g$. mules, donkeys, etc.) to draw the vehicles, the number depending on the importance of the route. Though the system evolved and developed over time its basic structure is already well attested in the first century AD.12

It appears that from inception the system was used for the transportation of Roman officials and soldiers travelling to take up posts or to carry out their duties. Only persons authorised to use the cursus publicus could travel by it. In view of Suetonius' note, it has been assumed that imperial couriers were also among those persons authorised to use it. From the above description it can been seen that in distinction from the postal systems of Persia and the Hellenistic kingdoms, which operated along a dedicated infrastructure, imperial couriers made use of a transportation system which was designed for other official travel as well.

A related consequence of Augustus' innovation was that the same courier now had to make the whole journey. As

of it by F. Preisigke, 'Die ptolemäische Staatspost', Klio 7 (1907) 241-77, and Llewelyn, 'Ptolemaic postal system'.

${ }^{12}$ See New Documents 7, 62-85. 
the iuvenes could no longer be used, Augustus resorted to the use of 'professional' couriers. The innovation also resulted in a slower service, for the courier will have had to stop for meals and rest. Speed was sacrificed for the sake of fuller information (i.e. the courier could be questioned) and a greater assurance that correspondence would not be lost by much handling.

There are a number of potential difficulties with the suggestion that there were Christian slaves/freedmen of Caesar's household who, as tabellarii, used the facilities of the cursus publicus and who could be imposed upon whilst performing their official duties to carry news between Paul in Rome and the community of believers situated at Philippi.

First, the suggestion rests on the assumption that tabellarii used the facilities of the imperial post. Opinion, however, is divided on this issue. Schroff ${ }^{13}$ alleges that, after the creation of the cursus publicus under Augustus, the tabellarii serving the state (called Augusti or Caesaris tabellarii) were not always issued with authorisations (i.e. diplomata) to use this network of relay stations and that, even when issued with diplomata, their use of the system might be restricted.

Seeck ${ }^{14}$ considers that most imperial tabellarii went on foot and justifies this by the existence of a special corps of tabellarii diplomarii who carried urgent messages and were entitled to use the cursus publicus. Kornemann 15 takes a different stance observing that 'all imperial tabellarii were authorised to use the official post and for this reason were occasionally called diplomarii'. Similarly Holmberg ${ }^{16}$ argues that it is absurd to suggest that the greatest part of official mail was transported by the tardy method of couriers travelling on foot. He concludes that 'the title tabellarius diplomarius should thusjust in the same way as the name Augusti or Caesaris tabellarius -only emphasise the political character of these couriers in distinction from the private tabellarii'.

${ }^{13}$ Schroff, 'Tabellarius', PW 2.IV, 1846-47.

${ }^{14} \mathrm{O}$. Seeck, 'Cursus publicus', PW IV, 1848.

${ }^{15} \mathrm{E}$. Kornemann, 'Postwesen', PW XXII, 1002.

16Holmberg, Cursus Publicus, 49-50. 
Pflaum ${ }^{17}$ takes yet another position. He argues that not all diplomata were issued for use of the cursus publicus; for example, in CIL VIII 1027 and OGIS 665 the diplomata appear to concern the provision of food and accommodation only. The tabellarii diplomarii were not a corps permanently attached to and the sole legitimate users of the cursus publicus-it is not until the time of Nerva that the system acquired its own personnel-but rather were attached to the various departments of civil administration and used to convey their correspondence. Only important imperial correspondence was conveyed by a tabellarius, issued with a diploma to use the cursus publicus. Even so, the issuing governor might feel compelled to explain his action. 18 The majority, it is argued, was carried by tabellarii using whatever means of transport they could find but equipped with diplomata entitling them only to food and accommodation along the way. In distinction from these government departments, the emperor and praefectus praetorio, as well as provincial governors with troops under their command, appear to have made use of soldiers (i.e. speculatores), no doubt issued with diplomata, to carry their correspondence. ${ }^{19}$

Since Pflaum's writing a new inscription has been published which further supports, albeit by an argument from silence, the view that tabellarii were only infrequently issued with diplomata entitling them to use the cursus publicus. The edict of the imperial legate Sex. Sotidius Strabo Libuscidianus. seeks to regulate the provision of transport and hospitium to travelling officials; the canon makes no mention of either the tabellarii or the speculatores who worked the cursus publicus as couriers. ${ }^{20}$ Mitchell observes that 'requisitions for the imperial

\footnotetext{
17H.-G. Pflaum, Essai sur le cursus publicus dans le Haut-Empire Romain (Paris: Mém. de 1'Acad. des Inscr. et Belles Lettres XIV. 1; 1940) 316-36.

${ }^{18}$ E.g. Pliny, Epist. 10.64; cf. also 63, 67, 83 and 106.

${ }^{19}$ Suetonius, Calig. 44.2, Tacitus, Hist. 2.73, Plutarch, Galba 8.4, and Mor. 522e. Cf. also Fergus Millar, The Emperor in the Roman World (London: Duckworth, 1977) 215-17. Millar, correctly I think, supposes that the messengers referred to by Josephus (AJ 18.163; cf. 18.158) and Philo (Leg. ad Gai. 202) were also soldiers.

20SEG XXVI 1392, AD 19.
} 
post only comprised a small fraction of the total amount of transport regularly commandeered under the empire'.21

Second, the text of Paul's letter gives no indication that the members of the familia Caesaris were actually tabellarii. The slaves and freedmen of Caesar performed numerous tasks, from those of domestic servants and sub-clerical functionaries through junior and intermediate clerical functionaries to senior administrative functionaries and provincial procurators and procurators of the important financial and administrative bureaux in Rome. Clerical and administrative functions were filled by members of the familia Caesaris, as the emperor was provided with few publicly-funded officials to assist him in his duties. From the time of Vespasian the higher procuratorial functions were increasingly filled by equites. ${ }^{22}$

It should also be noted that members of the familia Caesaris were not only located in Rome but stationed throughout the empire. Tabellarii belonged to the sub-clerical grades which had virtually no chance of access to the higher and more prestigious clerical grades. Their career consisted only of advancement within the corps of tabellarii, perhaps ending as an optio after manumission. They were slaves rather than freedmen and remained slaves during their period of service (from the age of 20 till 40). ${ }^{23}$ Their proportion as a percentage of the total number of the familia Caesaris is not known; however, I assume that the proportion was sufficiently small to make extremely hazardous any inference from Philippians 4:22 to the particular occupation of members of the familia Caesaris.

Third, a logistical problem appears to reside in the suggestion that the couriers were Christian. How many believing couriers in the service of the imperial postal must one postulate to assure a 'continuous passage of Christian intellig-

\footnotetext{
21S. Mitchell, 'Requisitioned transport in the Roman Empire: a new inscription from Pisidia', JRS 66 (1976) 129.

${ }^{22}$ Cf. A.H.M. Jones, Studies in Roman Government and Law (Oxford 1968) 158, and Millar, The Emperor, 59-60 and 69-83.

${ }^{23}$ See further P.R.C. Weaver, Familia Caesaris: A Social Study of the Emperor's Freedmen and Slaves (Cambridge: CUP, 1972) 227-9. On the ages of tabellarii see also G. Boulvert, Domestique et fonctionnaire sous le haut-empire romain (Paris: Belle Lettres, 1974) 150 n. 268.
} 
ence'? There is no evidence to suggest that the same couriers operated along the same route or to the same destination. Albeit that the via Egnatia, which passed through Philippian territory, formed part of the major link between Rome and her eastern provinces, not all couriers will have travelled this route. In season, sea travel offered, if not a faster, then at least a preferred means of transport to the eastern provinces of Asia, Bithynia, Syria, Egypt, etc.

As one might expect, evidence is slight for the actual routes taken by imperial couriers. From Josephus we learn that correspondence between Rome and the governor of Syria might be carried by sea. Journeys made by officials and other persons may also be cited in support of possible routes. ${ }^{24}$ Naturally, such journeys may not have been governed by the same contingencies. The journey of Ovid into exile may be cited as a first example. Banished to Pontus in AD 8 he travelled by sea to Corinth. After crossing the isthmus he travelled again by sea from Cenchreae to Imbros, then Samothrace and then Tempyra. From there he travelled by land. 25

A second example is provided by the journey of the younger Pliny to take up his governorship of Bithynia. ${ }^{26} \mathrm{He}$ travelled by boat around the Peloponnese to Ephesus. From Ephesus he travelled to Pergamum by land, completing his journey from there by coastal boat. Heat and prevailing winds are alleged as reasons for his choice of route. A third but hypothetical example is also relevant.

Marcus Aurelius, in a letter to Fronto cites part of a speech made by the latter before Antoninus Pius. The issue addressed by Fronto was the referral by the proconsul of Asia of a disputed will to the emperor and the precedent which his decision would set. Fronto assumes that the litigants in the referred matter would travel to Rome by sea. More importantly, he contends that if the precedent were set, then every will would be sent to Rome (presumably in a dispatch

24Josephus, $B J 2.203$ and $A J 18.305$.

25Ovid, Tristia 1.4, 1.10.1-23 and 1.11.1-8.

26Pliny, Epist. 10.15-17. 
from the provincial governor). Again he assumes that the transfer would be made by sea. 27

A fourth possible instance may be added. DuncanJones assumes that the ambassadors who carried Hadrian's letters back to Stratonicea in Lydia travelled by sea. ${ }^{28}$ The assumption is highly probable, though the text of the inscript-

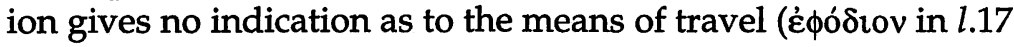
is not specific). It is not the intention of this article to argue that travel for the most part was by sea. It suffices to show that sea travel was frequent enough to render at risk the uncritical assumption that travel to the East was along the via Egnatia. ${ }^{29}$

The condition of the road itself and the likelihood of encountering inconvenience when travelling along it might influence a courier's choice of route. Two inscriptions found near Philippi record Trajan's repair of the via Egnatia (to Neapolis, AD 107, and to Acontisma, AD 112). 30 The inscriptions further record that the road had been neglected for a long time (viam ... longa intermissione neglectam restituendam curavit). Collart surmises that the road had probably been neglected from the time of the Republic, possibly since its establishment some time between 146 and $125 \mathrm{BC}$. Another consideration is also of relevance. The developed system of the cursus publicus was not created over-night. Roads elsewhere in the Empire were gradually paved and only in time were mansiones and mutationes established and a permanent personnel instituted (reign of Nerva).

27Ad M. Caes. 1.6.3,5.

28IGR IV $1156=A E$ (1949) 253, AD 127. R. Duncan-Jones, Structure and Scale in the Roman Economy (Cambridge: CUP, 1990) 26.

${ }^{29}$ For examples of travel to or from Rome along the via Egnatia, see Aelius

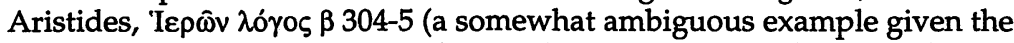
severe difficulties encountered in making the journey by land during

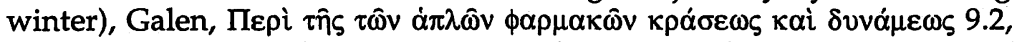
and Ignatius, Epist. ad Rom. 9.3, 10.3, and Epist. ad Polyc. 8.1. On the use of the via Egnatia by emperors usually travelling at the head of their armies, see P. Collart, Philippe: Ville de Macédoine depuis ses origines jusqu' à la fin de l'époque romaine (Paris: de Boccard, 1937) 510-19.

30See P. Collart, 'Une réfection de la via Egnatia sous Trajan', BCH 59 (1935) 395-415, and idem, Philippe, 509-10. 
Of further relevance is the inscription $M W 457,31$ which is dated to the reign of Vespasian. The document records a letter of the imperial procurator to the magistrates, boule and people of Thasos and seeks to end what was probably a long-running dispute between Thasos and Philippi over the boundaries of an estate and the dues payable on it for the maintenance of the cursus publicus. The document relates not to the upkeep of the road itself but to compulsory supply (angareia) of the cursus publicus. Such disputes will, no doubt, have also affected the efficiency of public transport and increased the difficulties associated with travel. 32

Uncertainty over whether official tabellarii were issued with diplomata entitling them to public transport is also a relevant consideration here. If they were infrequently issued with authorisations, then the difficulties associated with travelling long distances on foot or with procuring other means of transport may have persuaded many to find passage by boat. And let us remember that as part of the journey at least was by sea, the finding of a suitable passage at that point could influence the courier's choice of route. Again, even if the courier took the via Egnatia on a journey to one of the eastern provinces, it was not certain when or whether he would take the same route home. In sum, to assure a continuous flow of Christian communication given the vicissitudes of travel in the ancient world one must assume a sizeable corps of believing couriers. But is the assumption justified in this period?

Alternatively, one might assume that the members of Caesar's household were associated more particularly with the Philippian colony. Perhaps they were attached to the imperial administration there or, if the emperor owned any estates, mines or industrial establishments (e.g. dye-works) in the area, they may have been attached to one of these. Such assumptions might explain the alleged frequency of contact as well as the apparent familiarity between the members of Caesar's household and the Philippian church (Phil. 4:22). However, one must

${ }^{31}$ M. McCrum and A.G. Woodhead, Select Documents of the Principates of the Flavian Emperors (Cambridge: CUP, 1966) no. 457.

32 On the frequency of boundary disputes and their referral to Rome, see Millar, The Emperor, 425 and 435. 
be careful in multiplying hypotheses to validate a hypothesis. Moreover, the assumption does not explain why, at the time of Paul's writing, the members of Caesar's household were in Rome and not Philippi.

All potential difficulties disappear once it is realised that the identification of members of the familia Caesaris as tabellarii is unnecessary. This is so for the simple reason that the degree of unofficial (i.e. personal and commercial) travel would have been extensive enough to account for all unexplained communication. Indeed, as it will be shown below, only the third and fourth journeys come into consideration and these can be explained by simple return travel from Rome. One must remember that in antiquity private letters (and news) were carried by slaves, messengers, friends and acquaintances, not to mention strangers who happened to be travelling in the right direction. Indeed, writers frequently state as the reason for their writing the opportunity offered by a person travelling in the direction of the recipient (i.e. the so-called $\dot{\alpha} \phi \rho \mu \eta \dot{-}$-formula). How easy then was it to find a courier for one's letter? Koskenniemi ${ }^{33}$ argues that at least from the second century AD it was not as difficult as one might have suspected. He concludes that people were prepared to carry letters for others, thus assuring a reasonable pool of couriers and also that writers were willing to entrust their letters to them. The practice of entrusting letters to travellers is also attested in the first century. ${ }^{34}$ Cicero, for example, resorted to the practice and also advised his secretary, Tiro, to do the same (Cicero, Epist. ad Fam. 2.1.1, 16.5.2 and 16.6.2). Indeed, we may even need to consider the possibility that some of Paul's letters (i.e. Rom 1.115.33, Galatians and perhaps 1 and 2 Thessalonians) were delivered by such travellers. 35

${ }^{33} \mathrm{H}$. Koskenniemi, Studien zur Idee und Phraseologie des griechischen Briefes bis 400 n. Chr. (Helsinki: Suomalainen Tiedeakatemia, 1956) 64-7. See also New Documents 7, 27-8.

34BGU IV 1079 (AD 41), P. Oxy. VIII 1153 (first century), P. Bad. II 36 (AD 98-117) and BGU II 451 (first or second century); cf. also P. Oxy. II 269 (AD 57). The practice of giving letters to travellers predates the first century AD.

${ }^{35}$ See New Documents 7, 51-4. 
To return to the case under consideration here, the fact that Philippi lay on the main road link between Rome and her eastern provinces, as well as in reasonable proximity to the two major sea ports of Neapolis and Thessalonica, increased the possibility of finding someone to carry the news. If administrative officials or soldiers could not be prevailed upon to carry an oral or written message, then other travellers might. Of course, if such persons chose to travel along the via Egnatia, they were prohibited from the services offered by the cursus publicus; they were, however, free to use the road paying for whatever transport and accommodation they required. Alternatively, they may have made the journey by sea. It should also be borne in mind that letters were not necessarily sent directly to their addressees. Often we find them sent to a third party who could be trusted to forward them on. ${ }^{36}$ In other words, one did not have to find a traveller going specifically to Philippi in order to effect delivery. A traveller to Thessalonica may have sufficed, with the Christians there seeing to the final stage of delivery.

\section{New Testament Data}

Of the seven journeys either made or anticipated, only three (the first, third and fourth) permit Hemer's suggestion. However, internal evidence in support of the suggestion is lacking. The text of Philippians gives no indication that the members of the familia Caesaris referred to at Philippians 4:22 were employed with the imperial post. As has already been noted, numerous other offices or functions could have claimed their services or labour. Furthermore, both the form and means of the communication facilitated by the first, third and fourth journeys are uncertain.

Other explanations can be offered for each communication. In particular, a more plausible explanation of the first communication can be offered, namely that the news of Paul's departure for trial in Rome was carried by one of Paul's fellow-

${ }^{36}$ See S.R. Llewelyn, 'The eis ( letters to third persons or to their property', ZPE 101 (1994) 71-8, and New Documents 7, 38-43. 
workers travelling from Caesarea. Paul would have wished his supporters in Philippi and elsewhere to be informed of his departure as soon as possible.

Information of new developments will not have been Paul's only concern. Prisoners were largely supported at their own expense or by their relatives and friends. In Caesarea Paul was supported during his imprisonment by friends (Acts 24:23). In Rome Paul had the added cost of rented accommodation. ${ }^{37}$ Who paid for this? Rapske argues that as Paul could not practise his trade in Rome, he supported himself from his inheritance. ${ }^{38}$ However, as evidence for Paul's independent means is wanting, it seems preferable to assume that Paul was largely maintained through the support of the churches which he founded. If Paul was now going to seek support from the Macedonian churches, he would do best to let them know in advance of his arrival in Rome. That Paul sought support is implicit in what he says at Philippians 4:10-19, especially 4:17.

Is there a candidate for this journey? Acts 27:2 records that Aristarchus, a Macedonian of Thessalonica and fellowworker of Paul (Acts 19:29, 20:4, Col. 4:10 and Phm. 24), boarded the boat with the apostle. He had accompanied Paul to Jerusalem (probably as one of the congregational agents of the collection) and apparently stayed with Paul for his two years of imprisonment in Caesarea. Who better than Aristarchus, a Macedonian, to accomplish the task of informing Paul's supporters in that province! Indeed, John Chrysostom tells us that this was precisely what Aristarchus did ('Aristarchus was auspiciously and usefully at hand to report everything to Mace-

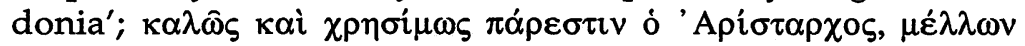

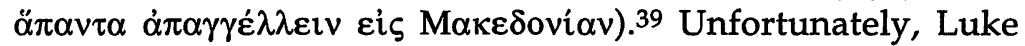
does not inform us where Aristarchus alighted. Disembarking with Paul at Myra in Lycia, Aristarchus may have travelled by land through the provinces of Asia and Macedonia, or again he may have found passage on another ship or, if the same ship

37 See Acts 28:30. On the provision of a prisoner's daily needs, see B. Rapske, Paul in Roman Custody (Grand Rapids: Eerdmans, 1994) 209-13, 236-9.

38Ibid, 106-324-26.

${ }^{39}$ In Acta apostolorum 60.367. 
was continuing on to Adramyttium (cf. Acts 27:2), he may have stayed on board up to that point and then sought another boat crossing to Macedonia.

There are, however, difficulties with identifying Aristarchus as the messenger. First, if Colossians and Philemon, which name Aristarchus as present with Paul (Col. 4:10 and Phm. 24), were written from Rome, then the presumption might be that he accompanied Paul to Rome. Second, the naming of Aristarchus at the beginning of the voyage (i.e. at the beginning of the Lukan 'we-passage', Acts 27:1-28:16) with no mention of his disembarking presupposes that he travelled to Rome with Paul. But the issue is not clear-cut.

It seems unlikely that Colossians and Philemon were written from Rome. The evidence tilts decisively in favour of Colossians and Philemon having been written during another imprisonment, possibly in Ephesus. A number of considerations point to their composition in an area in close proximity to Colossae. For example, the command issued to Philemon, who lived in Colossae, to prepare quarters for Paul (Phm. 22) makes more sense if his imprisonment was nearby and release imminent. The presence of Oneșimus, Philemon's runaway slave, is a strong indication for Paul's presence in the metropolis of Ephesus. It is improbable that a fugitive, for whatever reason, would need or be able to travel either to Caesarea or Rome to escape his master. The presence of Epaphras (Col. 4:12 and Phm. 23), the evangelist of Colossae, is also easier to explain if Paul was imprisoned in Ephesus rather than Caesarea or Rome. Again, still other considerations point to a composition in Ephesus. There is no evidence for Aristarchus' presence at Rome in the tradition (e.g. Acts, Philippians or 2 Timothy). But Acts does record his presence with Paul on the 'third

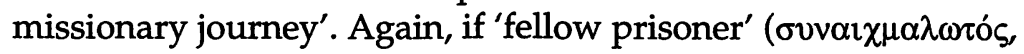
$\mathrm{Phm}$. 23) is not to be taken as merely metaphorical, then an Ephesian composition at least offers some explanation for Aristarchus' imprisonment, for he was known to the authorities there (Acts 19:29) and may have been the subject of a court action (Acts 19:38). Acts 20:4 does not preclude such a possibility. It may also be worth considering that the hypothesis of Roman composition implies the presence of both Timothy and 
Mark (Col. 1:1, 4:10, Phm. 1 and 24) in Rome. As Colossae in all probability suffered considerable destruction in the earthquake of AD 60 and no mention of the disaster is made within the context of either letter, it follows that Colossians and Philemon, if composed in Rome, must have been written early in Paul's imprisonment there. However, the tradition holds that neither was in Rome at this time (2 Tim. 1:16-18 and 4:9-11). Lastly, it may be noted that the Marcionite prologue to Colossians indicates Ephesus as the place of writing. ${ }^{40}$

If against the evidence one still wishes to maintain that the letters were composed in Rome, the presence of Aristarchus can be easily explained, for it is not necessary to assume that he took the same route as Paul all the way. Indeed, it is eminently sensible that he should take the land route to Rome, informing the Pauline churches along the way of the apostle's fate.

The second difficulty is more problematic. Lüdemann identifies the naming of Aristarchus at Acts 27:2 as possibly part of Luke's received tradition.41 Alternatively, Conzelmann holds that it was intended as a reference to the way in which Luke came upon his material. 42 Both positions might be used to argue for the factuality of Aristarchus' accompaniment of Paul. Arguments against the positions might be mounted, e.g. that the tradition was mistaken or that as Aristarchus accompanied Paul on his last journey to Jerusalem (Acts 19:29 and 20:4), the naming of Aristarchus at the beginning of the voyage is merely a Lukan inference (redactional). However, it seems preferable to admit the difficulty posed by Acts 27:2. But this does not mean that one need dismiss the Caesarean origin of the first journey. If Aristarchus did not make the journey, then news was sent through another messenger or channel. Of course, there is no direct evidence for this journey. But then again there is also no direct evidence that the Philippians only heard of Paul's plight after his arrival in Rome. The feasibility of a Caesarean origin rather rests on the assumption that Paul

40I leave aside the issue of composition in Caesarea as this does not contradict the present argument.

${ }^{41} \mathrm{G}$. Lüdemann, Das frühe Christentum (Göttingen: Vandenhoeck and Ruprecht, 1987) 268.

42H. Conzelmann, Die Apostelgeschichte (Tübingen: Mohr, 1972) 151. 
would take what steps he could to meet the exigencies imposed by his transfer to Rome.

In regard to the third and fourth journeys two points can be made. First, the communication can be explained by one messenger making a simple return voyage to Philippi. This possibility, together with the alternative explanation of the first communication, greatly weakens the premise on which Hemer bases his inference, namely that there was a continuous and unexplained passage of Christian intelligence between Rome and Philippi. One unexplained return voyage does not constitute a continuous passage of intelligence. Second, a more precise identification of the messengers can be suggested.

Paul's judgement at Philippians 2:20-21 is harsh. In these verses the apostle talks about the anticipated journey of Timothy to the Philippians (i.e. the sixth journey). However, Paul does not only commend Timothy but also offers what appears to be a general criticism of all his other companions. The criticism does not sit well with the concluding greetings (Phil. 4:21-22), if one assumes that the same persons are referred to in both passages. Why add the greetings of those who elsewhere in the letter are described as unconcerned for the Philippians' welfare? Moreover, how could such persons give tacit consent to a letter, if it so represented them? The harsh judgement is, however, consistent with the description of those who proclaimed Christ from base motives and sought to cause Paul distress (Phil. 1:15-17). No doubt, this group of 'brothers' was excluded from 'the brothers who are with me' in

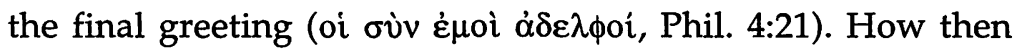
does one explain Philippians 2:19-21? The identity of those who made the third and fourth journeys provides the answer. It seems probable that the messengers were in some way associated with those who sought to cause Paul distress in his imprisonment (Phil. 1:17).

A number of factors point in this direction. First, news of Epaphroditus' illness caused the Philippians concern and this in turn caused Paul distress (Phil. 2:28). Of course, this only shows the effect of the news and not the intention of those who brought it; however, it is an important starting point in identifying the messengers. 
Second, the source of the news of Epaphroditus' illness does not appear to have been Paul, Timothy or Epaphroditus. Indeed, if the news had been brought by those associated with Paul in Rome, it seems somewhat odd that Paul did not also ask them to carry his thanks for the Philippians' gift. His thanks is first offered at Philippians 4:10-20 ( $c f$. also Phil. 1:7). The delay in Paul's response to the gift also raises doubts over the supposed 'continuous passage of Christian intelligence' between Rome and Philippi.

Third, the harshness and reference difficulties of Philippians 2:20-21 are easily explained under the hypothesis that the messengers represented 'brothers' who were hostile to Paul. To understand these verses it is necessary to appreciate their context. The surrounding passage concerns past, present and future journeys (the so-called travelogue, Phil. 2:19-30). In all, the verb 'to send' ( $\pi \varepsilon \dot{\varepsilon} \mu \omega)$ is used four times and five of our seven journeys (i.e. journeys 3 to 7 ) are mentioned. It is also necessary to understand that, although we do not hear of the third and fourth journeys until v.26, the Philippians are of course fully aware of them. So when considering Philippians 2:20-21, we need to be conscious that Paul had a number of journeys on his mind at the time and that the Philippians were already appraised of those which had occurred. Accordingly, the somewhat awkward disavowal of Philippians 2:20-21 begins to make sense. Paul intended (and the Philippians would naturally have construed) the criticism as engendering an aspersion against the most recent messengers to have carried news between Rome and Philippi (i.e. on the third and fourth journeys). The presumption is that these messengers were in Rome and might have been used by the apostle in future communication. Paul, however, cannot contemplate sending them. Only Timothy is trusted as the 'like-minded' emissary of the apostle (iøó $v 0 \chi 0 \varsigma$, Phil. 2:20). The others show no concern for the welfare of the Philippians. They act only in their own interests and not those of Christ, (Phil. 2:20-21; $c f$. 
Phil. 1:15-17 where feelings of envy and rivalry prompt Paul's adversaries to cause him distress. $)^{43}$

Other explanations for the harshness of Paul's judgement against his associates are offered. For example, Hainz ${ }^{44}$ argues that Philippians 2:19-24 constitutes Paul's recommendation of Timothy as his successor and that the passage was prompted by the apostle's uncertainty over his future. The negative appraisal of his other associates only served to emphasise the integrity of Timothy, placing it in a clearer light. The interpretation is problematic for several reasons: (a) Paul did not need to denigrate others merely to indicate his chosen successor. Indeed, it is difficult to explain the harshness of the judgement as purely literary, i.e. to highlight or to emphasise the integrity of Timothy. One must assume that Paul's comments were prompted by the attitude and actions of his associates. (b) The passage gives no indication that Timothy was recommended as Paul's successor. The apostle does not name Timothy as his successor. One must ask why Paul was so vague if this was his intention. (c) Hainz recognises two difficulties for his interpretation, namely the portrayal of Timothy's subordinate position vis-à-vis the apostle (v.22) and Paul's hope that he would soon be released and be able to visit the Philippians in person (v.24).

If the above interpretation of the evidence proves correct, then it is highly improbable that those making the third and fourth journeys were the slaves and/or freedmen of Caesar's household mentioned in the final greetings of the letter. The internal evidence of the letter offers no support for the hypothesis that 'those of Caesar's household' (Phil. 4:22) were couriers able to use the imperial post.

In conclusion, could believing couriers in the imperial service have carried news between Paul and the Philippians? If one is interested in the mere possibility, then the answer is 'yes'. The more interest-ing question, however, is whether the suggestion is at all probable. Internal and external evidence has

${ }^{43}$ The verses are otherwise awkward, for Timothy is evidently not

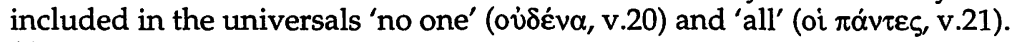
${ }^{44} \mathrm{~J}$. Hainz, Ekklesia: Strukturen paulinischer Gemeinde-Theologie und Gemeinde-Ordnung (Regensburg: Poster, 1972) 210-14. 
been adduced against which a more informed assessment of the suggestion can be made, in particular: (a) each instance of communication can be explained in a way which does not require the hypothesis that the imperial post was used; (b) the evidence of the three unexplained journeys does not justify the description 'continuous passage'; (c) to identify the function of the members of Caesar's household (Phil. 4:22) as couriers is very risky; (d) to explain the communication by an appeal to the use of couriers in the service of the emperor is problematic in a number of ways; and (e) the communication can be more easily explained by the use of a private traveller or travellers.

Furthermore, there was no public system for the conveyance of private letters or news in antiquity. Individuals had instead to rely on the use of messengers or willing travellers. As there is little evidence for the use of imperial couriers for this purpose, the communications between Rome and Philippi are better accounted for under the assumption of a return voyage from Rome either made by one of the apostle's opponents or arranged by one of them. Furthermore, the likelihood that the Philippians first heard of Paul's appeal to Caesar and his dispatch to Rome from Caesarea removes an important obstacle to the hypothesis of the letter's Roman provenance. In fact, given the delays to Paul's voyage caused by the season of travel, it is quite possible that Epaphroditus was already in Rome awaiting the apostle's arrival. If so, only the third and fourth journeys should be factored into any calculation of the period between Paul's arrival in Rome and the writing of his letter to the Philippians. There is more than enough time for all transfers of information to occur within the apostle's two-year stay in Rome. And if an explanation of Epaphroditus' illness is to be sought, one need look no further than the risks to health posed by a winter journey. 45

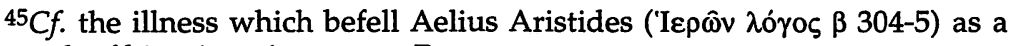
result of his winter journey to Rome. 